\title{
Pengaruh Penggunaan Metode Mind Mapping terhadap Keterampilan Berpikir Kreatif Siswa Kelas X SMA Negeri 2 Balaesang
}

\author{
Efi, Darsikin, dan Sahrul Saehana \\ efhymunir@gmail.com \\ Program Studi Pendidikan Fisika FKIP Universitas Tadulako \\ Jl. Soekarno Hatta Km. 9 Kampus Bumi Tadulako Tondo Palu - Sulawesi Tengah
}

\begin{abstract}
Abstrak - Penelitian ini bertujuan untuk mengetahui perbedaan keterampilan berpikir kreatif antara kelompok siswa yang diberi perlakuan metode Mind Mapping dengan kelompok siswa yang diberi perlakuan dengan model konvensional pada kelas X SMA Negeri 2 Balaesang. Metode yang digunakan adalah eksperimen kuasi dengan equivalent pretest-posttest design. Populasi penelitian ini adalah seluruh siswa kelas X SMA Negeri 2 Balaesang. Teknik pengambilan sampel adalah purposive sampling. Kelas XA sebagai kelas eksperimen dan kelas XB sebagai kelas kontrol. Instrumen yang digunakan pada penelitian ini berupa tes esai yang telah divalidasi. Persentase rata-rata keterampilan berpikir kreatif yang mengikuti metode Mind Mapping adalah $67,35 \%$ yang berkriteria kreatif dan persentase rata-rata yang mengikuti pembelajaran konvensional adalah $63,39 \%$ yang berkriteria kreatif. Hasil perhitungan statistik dari pengujian hipotesis menggunakan uji-t didapatkan harga $t_{\text {hitung }}$ sebesar 0,90 dan $t_{\text {tabel }} 2,00$ pada taraf signifikansi $5 \%$ dan dk $=72$. Disimpulkan bahwa tidak terdapat perbedaan yang signifikan keterampilan berpikir kreatif siswa yang mengikuti metode Mind Mapping dengan pembelajaran konvensional pada kelas X SMA Negeri 2 Balaesang.
\end{abstract}

Kata Kunci : Metode Mind Mapping, Keterampilan Berpikir Kreatif

\section{PENDAHULUAN}

Pendidikan merupakan jembatan untuk setiap manusia meraih kesuksesan dalam hidupnya, yakni melalui proses belajar mengajar untuk dapat mengubah pola pikir dan tingkah laku kearah yang lebih maju, agar dapat melahirkan sumber daya manusia yang berkualitas dan mampu menguasai ataupun menciptakan teknologi mutakhir seperti saat ini. Seiring dengan perkembangan zaman, pendidikan sains (IPA) seperti pendidikan pada umumnya memiliki peranan yang sangat penting dalam pembentukkan kepribadian dan perkembangan intelektual anak

Pembelajaran yang menyenangkan dapat dilakukan dengan cara melibatkan siswa secara penuh sebagai obyek bukan sebagai subyek. Dalam dunia pendidikan, pemilihan metode yang tepat adalah dengan penyesuaian karakteristik materi, pelajaran, siswa, lingkungan, dan sarana-prasarana dapat memberdayakan potensi siswa .

Berpikir kreatif (Creative Thinking) adalah suatu proses berpikir yang mampu memecahkan masalah dengan cara yang orisinil dan berguna. Dalam hal ini metode Mind Mapping menjadi salah satu metode yang digunakan untuk mengatasi kondisi siswa yang kurang aktif dan kreatif keterlibatannya dalam kegiatan pembelajaran. Pertimbangan lain yang memperkuat alasan pemilihan metode Mind
Mapping yaitu: mudah dilakukan, menyenangkan, optimalisasi otak secara keseluruhan, serta kesesuaian metode dengan karaktersistik siswa dan materi IPA fisika.

Tujuan penelitian ini adalah untuk mengetahui pengaruh penggunaan metode Mind Mapping terhadap keterampilan berfikir kreatif siswa kelas X SMA Negeri 2 Balaesang.

\section{METODE PENELITIAN.}

Penelitian ini menggunakan penelitian eksperimen semu (quasi experiment). Metode penelitian ini menggunakan desain non equivalen control group design, hanya pada desain ini kelompok eksperimen maupun kontrol tidak dipilih secara random .

Adapun desain penelitian menggunakan Rancangan Pretes-Posstes Desain penelitian ini digambarkan pada Tabel 1.

TABEL 1 DESAIN PENELITIAN

\begin{tabular}{cccc}
\multicolumn{1}{c}{ Kelas } & Pretest & Perlakuan & posstest \\
\hline Eksperimen & $\mathrm{O}$ & $\mathrm{X}$ & $\mathrm{O}$ \\
Kontrol & $\mathrm{O}$ & - & $\mathrm{O}$ \\
\hline
\end{tabular}

Keterangan :

O : Tes awal dan tes akhir

$\mathrm{X}$ :Perlakuan dengan metode Mind Mapping

Populasi dalam penelitian ini yaitu seluruh siswa kelas X SMA Negeri 2 Balaesang tahun ajaran 2015/2016. Sampel dari penelitian ini 
p-ISSN 2338-3240, e-ISSN 2580-5924

adalah kelas XA sebagai kelas eksperimen dan XB sebagai kelas kontrol.

Penarikan sampel pada penelitian ini ditentukan dengan menggunakan tekhnik purposive sampling atau penentuan sampel dengan pertimbangan tertentu. Dua kelas yang dijadikan tempat penelitian ini adalah kelas yang diajar oleh guru yang sama. Satu kelas diberikan metode Mind Mapping (kelas eksperimen) dan satunya lagi menggunakan pembelajaran konvensional (kelas kontrol).

Instrumen yang digunakan dalam penelitian ini adalah tes essay. Tes digunakan untuk melihat keterampilan berpikir kreatif siswa. Tes essay sebanyak 5 item yang dilakukan sebanyak dua kali pengujian, yaitu pada tahap awal sebelum perlakuan (pretest) dan tahap akhir setelah perlakuan (posttest). Untuk memperoleh tes yang standar, dilakukan validasi tes berupa validitas ahli.

Data yang diperoleh dari penelitian ini selanjutnya diolah dengan menggunakan uji statistik berupa uji normalitas, uji homogenitas, dan uji hipotesis. Dengan uji-t dua pihak.

\section{HASIL DAN PEMBAHASAN}

Instrumen keterampilan berpikir kreatif berjumlah 10 item yang di susun peneliti dan selanjutnya divalidasi oleh validator ahli. Setelah divalidasi oleh ahli dinyatakan bahwa 7 item yang dinyatakan valid. Kemudian dari 7 item tersebut peneliti memilih 5 item yang mewakili masing-masing indikator dari keterampilan berpikir kreatif siswa yaitu 2 item untuk indikator berpikir lancar, 1 item untuk berpikir luwes, 1 item untuk berpikir original dan 1 item untuk elaborasi. Kelima item inilah yang digunakan peneliti untuk mengukur keterampilan berpikir kreatif siswa pada kelas yang dijadikan sampel.

Pada postest yang diberikan pada kelas eksperimen dan kelas kontrol maka diperoleh hasil untuk kelas eksperimen nilai minimum 40,00 dan nilai maksimum 90,00. Nilai ratarata pada kelas eksperimen sebesar 67,35 dengan standar deviasi 15,22. Pada kelas kontrol diperoleh nilai minimum 40,00 dan nilai maksimum 85,00. Untuk nilai rata-rata pada kelas kontrol 63,39 dengan standar deviasi 13,94. Hasil posttes di atas, disajikan pada Tabel 2.

Berdasarkan Tabel 2, dapat dilihat bahwa secara kuantitas terdapat perbedaan keterampilan berpikir kreatif siswa sebelum dan sesudah diterapkannya metode Mind Mapping pada kelas eksperimen dan pembelajaran konvensional pada kelas kontrol, tetapi perbedaannya tidak signifikan.
TABEL 2 DESKRIPSI NILAI TES KETERAMPILAN BERPIKIR KREATIF SISWA UNTUK KELAS EKSPERIMEN DAN KELAS KONTROL

\begin{tabular}{|c|c|c|}
\hline \multirow[t]{2}{*}{ Uraian } & Kelas Kontrol & $\begin{array}{c}\text { Kelas } \\
\text { Eksperimen }\end{array}$ \\
\hline & Tes Akhir & Tes Akhir \\
\hline Jumlah siswa & 37 & 37 \\
\hline Nilai Minimum & 40,00 & 40,00 \\
\hline Nilai Maksimum & 85,00 & 90,00 \\
\hline Nilai Rata-rata & 63,39 & 67,35 \\
\hline Simpangan Baku & 13,94 & 15,22 \\
\hline
\end{tabular}

Hasil analisis deskriptif keterampilan berpikir kreatif siswa dapat dilihat pada Tabel 3.

TABEL 3 ANALISIS DESKRIPTIF KETERAMPILAN BERPIKIR KREATIF SISWA

\begin{tabular}{ccc}
\hline $\begin{array}{c}\text { Aspek yang } \\
\text { diamati }\end{array}$ & Kelas Kontrol & Kelas Eksperimen \\
\cline { 2 - 3 } $\begin{array}{c}\text { Berpikir } \\
\text { Lancar }\end{array}$ & $\begin{array}{c}47,63 \text { (Cukup } \\
\text { Kreatif) }\end{array}$ & $\begin{array}{c}\text { Tes akhir }(\%) \\
\text { Kreatif) }\end{array}$ \\
Berpikir Luwes & $\begin{array}{c}\text { K3,11 (Kurang } \\
\text { Kreatif) }\end{array}$ & $\begin{array}{c}35,14 \text { (Kurang } \\
\text { Kreatif) }\end{array}$ \\
Berpikir & $\begin{array}{c}4,90 \text { (Kurang } \\
\text { Kreatif) }\end{array}$ & $\begin{array}{c}39,19 \text { (Kurang } \\
\text { Kreatif) }\end{array}$ \\
Original & 38,51 (Kurang \\
Kreatif) & $\begin{array}{c}38,51 \text { (Kurang } \\
\text { Kreatif) }\end{array}$ \\
Raborasi & & 40,80 (Kurang \\
& 40,29 (Kreatif) & Kreatif)
\end{tabular}

Persentase deskripsi keterampilan berpikir kreatif siswa pada kelas eksperimen pada tingkat berpikir lancar adalah 50,34\% (Cukup Kreatif) dan kelas kontrol 47,63\% (Cukup Kreatif). Hal ini menyatakan bahwa pada inidikator berpikir lancar ini tidak terdapat perbedaan yang signifikan keteramplan berpikir lancar diantara kedua kelas yang menggunakan metode Mind Mapping dan pembelajaran konvensional karena keduanya baik dalam menggali keterampilan berpikir lancar siswa tersebut.

Pada indikator berpikir luwes kelas eksperimen dengan metode Mind Mapping mendapatkan persentase $35,14 \%$ (kurang kreatif) sedangkan kelas kontrol dengan pembelajaran konvensional mendapatkan $33,11 \%$ (kurang kreatif). Pada indikator ini terdapat perbedaan dari segi kuantitatif tetapi dari segi kualitatif tidak terdapat perbedaan karena kategori nilai yang dipeoleh kedua kelas masih dalam kategori kurang kreatif.

Indikator berpikir original pada kelas eksperimen adalah $41,90 \%$ sedang kelas kontrol 39,19\%. Pada indikator ini terdapat perbedaan dari segi kuantitatif tetapi dari segi kualitatif tidak terdapat perbedaan karena kategori nilai yang dipeoleh kedua kelas masih dalam kategori kurang kreatif. 
Indikator berpikir elaborasi pada kelas eksperimen adalah $38,51 \%$ dan kelas kontrol adalah $38,51 \%$. Pada indikator berpikir original tidak terdapat perbedaan.

Hasil uji hipotesis siswa pada kelas kontrol dan eksperimen dapat dilihat pada Tabel 4.

TABEL 4 HASIL UJI HIPOTESIS

\begin{tabular}{|c|c|c|c|c|c|}
\hline \multirow[b]{2}{*}{ No } & \multicolumn{3}{|c|}{ Nilai rata- } & \multirow[b]{2}{*}{$t_{\text {tabel }}$} & \multirow[b]{2}{*}{ Keputusan } \\
\hline & Nilai & rata $\bar{X}$ & $t_{\text {hitung }}$ & & \\
\hline 1 & $\begin{array}{c}\text { Eksperime } \\
\mathrm{n}\end{array}$ & 63,75 & & & \\
\hline 2 & Kontrol & 63,39 & 0,90 & 2,00 & $\mathrm{H}_{0}$ diterima \\
\hline
\end{tabular}

Berdasarkan data pada Tabel 4 diketahui $2,00<0,90<2,00$. Hal ini berarti, nilai $t_{\text {hitung }}$ berada di dalam daerah penerimaan $\mathrm{H}_{0}$. Dengan demikian $\mathrm{H}_{0}$ diterima dan $\mathrm{H}_{1}$ ditolak, dan dapat disimpulkan bahwa pada keadaan akhir tidak terdapat perbedaan keterampilan berpikir kreatif pada siswa yang menerima metode mind mapping dengan siswa yang menerima pembelajaran konvensional.

Hasil dari penelitian ini dalam penerapan metode Mind Mapping dan pembelajaran konvensional pada kelas eksperimen dan kontrol tidak memberikan perbedaan yang sangat signifikan. Akan tetapi keterampilan berpikir kreatif siswa yang mengikuti metode Mind Mapping hasilnya lebih baik dari pada keterampilan berpikir kreatif siswa yang mengikuti pembelajaran konvensional.

Metode Mind Mapping sendiri dapat meningkatkan keterampilan berpikir kreatif karena pembelajaran menggunakan metode Mind Mapping siswa diajak membuat materi pelajaran terpola secara visual dan grafis yang akhirnya dapat membantu merekam, memperkuat, dan mengingat kembali informasi yang telah dipelajari, sehingga dapat meningkatkan keterampilan bepikir kireatif siswa. Rata-rata keterampilan berpikir kreatif siswa untuk kelas eksperimen tidak memiliki perbedaan yang signifikan dibandingkan dengan kelas kontrol. Namun, bukan berarti kedua model ini tidak mempunyai kekurangan.

Kelebihan dari metode Mind Mapping yang digunakan di kelas eksperimen adalah: (1) meningkatkan kreativitas dan aktivitas individu maupun kelompok; (2) memudahkan otak memahami dan menyerap informasi dengan cepat; (3) meningkatkan daya ingat; (4) mengakomodasi berbagai sudut pandang terhadap suatu informasi.; (5) memusatkan perhatian siswa; (6) menyenangkan
Penerapan metode pembelajaran ini, peneliti juga mendapatkan kesulitan yaitu sulit mengontrol siswa dalam pembuatan Mind Mapping kurang maksimal, terlalu banyaknya tugas siswa diluar mata pelajaran fisika. Selain itu, walaupun sudah mengatur alokasi waktu yang cukup masih saja memerlukan waktu yang lebih banyak untuk pembuatan Mind Mapping tersebut sehingga pencapaian hasil yang kurang maksimal.

Keunggulan pembelajaran konvensional yang diterapkan di kelas kontrol adalah (1) merupakan teknik yang cukup bagus untuk memahami isi pelajaran. (2) dapat menantang kemampuan siswa serta memberikan kepuasan untuk menemukan pengetahuan baru bagi siswa. (3) dapat meningkatkan aktivitas pembelajaran siswa. (4) dapat membantu siswa untuk bagaimana mentransfer pengetahuan mereka untuk memahami masalah dalam kehidupan nyata, dan (5) dapat membantu siswa untuk mengembangkan pengetahuan barunya. Sedangkan kekurangan dari pembelajaran konvensional ini adalah guru kesulitan dalam merubah gaya mengajar, (1) Memerlukan lebih banyak waktu untuk siswa dalam memecahkan masalah, jika model tersebut baru diperkenalkan dikelas. (2) Setiap kelompok boleh menyelesaikan tugas sebelum atau sesudahnya. (3) Sukar menerapkan pembelajaran konvensional dalam semua kelas serta (4) Kesulitan dalam menilai pelajaran.

Di luar permasalahan yang menyangkut kekurangan metode yang digunakan, metode ini juga baik untuk digunakan disekolah agar siswa lebih aktif dalam proses belajar dibandingkan metode-metode yang sebelumnya dilakukan disekolah dimana siswa lebih banyak mendengarkan. Selain itu faktor lain yang harus menjadi perhatian adalah kondisi siswa yang beragam sehingga diluar jangkauan peneliti. Namun, peneliti tetap merekomendasikan metode ini untuk diterapkan dalam proses belajar mengajar di sekolah karena ketika pembelajaran ini diterapkan dengan baik dan benar maka hasil yang diharapkan akan lebih maksimal.

\section{KESIMPULAN}

Berdasarkan hasil penelitian, diperoleh nilai rata-rata keterampilan berpikir kreatif siswa serta standar deviasi pada tes awal untuk kelas eksperimen yaitu 42,91, 10,25 dan untuk kelas kontrol yaitu 43,76, 8,60. Setelah diberikan perlakuan diperoleh nilai rata-rata keterampilan berpikir kreatif siswa pada materi dinamika gerak serta standar deviasinya pada tes akhir untuk kelas eksperimen $(67,35),(15,22)$ dan 
untuk kelas kontrol $(63,39),(13,94)$. Rata-rata persentase keterampilan berpikir kreatif siswa pada kelas eksperimen dan kontrol adalah $63,85 \%$ dan $61,57 \%$. Nilai signifikan hasil uji hipotesis diperoleh $t_{\text {hitung }}<t_{\text {tabel }} 0,90<2,00$ sehingga $\mathrm{H}_{\mathrm{o}}$ diterima dan $\mathrm{H}_{1}$ ditolak. Dengan demikian dapat disimpulkan bahwa terdapat perbedaan dari segi kuantitatif tetapi dari segi kualitatif tidak terdapat perbedaan karena kategori nilai yang dipeoleh kedua kelas masih dalam kategori kurang kreatif.

\section{DAFTAR PUSTAKA}

[1] Abdullah, R. (2016). Pengaruh Model Project Based Learning Terhadap Keterampilan Berpikir Kreatif Siswa Pada Materi Dinamika Gerak Kelas X MA Negeri 2
Model Palu. Skripsi. Program Studi Pendidikan Fisika. Universitas Tadulako Palu

[2] Riadi, M. (2014). Pengertian Mind Mapping. [Online]. Tersedia:http://www.kajianpustaka.com/2014/01/pen gertian-manfaat-dan-membuat-mind.html [29november 2015]

[3] Salfina. 2015. Pengaruh metode mind mapping terhadap keterampilan berfikir kreatif dan kemampuan berkomunikasi tentang fisika siswa kelas VII SMP Negeri 1 Biromaru. Tesis Magister pada Pascasarjana Universitas Tadulako: tidak diterbitkan.

[4] Sudrajat, A. (2013). Mind map (peta pikiran). [online].Tersedia:https://akhmadsudrajat.wordpress.c om/2013/09/09/mind-map-peta-pikiran/ november 2015]

[5] Sugiyono . (2013). Metode Penelitian Pendidikan Pendekatan Kuantitatif, Kualtitatif dan R\&D. Bandung: Alfabeta

[6] Wijipurnomo. (2013). Pembelajaran konvensional teknologi pembelajaran. [online]. Tersedia:https://djamhran.Wordpress.com/2013/09/0 9 [07 desember 2016] 